Volume 7 Nomor 1 Tahun 2019

\title{
Penggunaan Model Open Ended Learning untuk Meningkatkan Kemampuan Pemecahan Masalah dalam Pembelajaran Matematika Di Kelas V SD Negeri 2 Mekarsari Tahun Ajaran 2017/2018
}

\author{
1,2,3 Universitas Sebelas Maret \\ murcahyani10@gmail.com
}

${\text { Murcahyani }{ }^{1} \text {, Suhartono }}^{2}$, Moh. Salimi ${ }^{3}$

\section{Article History}

accepted 01/02/2019

approved 01/03/2019

published 01/04/2019

\begin{abstract}
The objective of this research is to improve problem solving ability in Mathematics learning through the use of Open Ended Learning model. This research is a collaborative Classroom Action Research (CAR) conducted within three cycles. Subjects of the research were teacher and the fifth-grade students. Techniques of collecting data were observation, interview, and test. Validity of data in this research was analyzed using triangulation of sources and triangulation of technique. Data analysis consists of data reduction, data display, and drawing conclusion. The results of this research showed that the use of Open Ended Learning can improve problems solving ability in Mathematics learning for the fifth-grade students.
\end{abstract}

Keywords: Open Ended Learning, the ability to solve problem, Mathematics

\begin{abstract}
Abstrak
Tujuan penelitian ini yaitu untuk meningkatkan kemampuan pemecahan masalah siswa dalam mata pelajaran Matematika melalui penggunaan model Open Ended Learning. Penelitian ini merupakan penelitian tindakan kelas (PTK) kolaboratif yang dilaksanakan dalam tiga siklus. Subjek penelitian ini adalah guru dan siswa kelas $\mathrm{V}$. Teknik pengumpulan data menggunakan observasi, wawancara, dan tes. Validitas data menggunakan triangulasi teknik dan sumber. Analisis data meliputi reduksi data, penyajian data, dan kesimpulan. Hasil penelitian ini menunjukkan bahwa penggunaan model Group Open Ended Learning dapat meningkatkan kemampuan pemecahan masalah siswa dalam mata pelajaran Matematika kelas V.
\end{abstract}

Kata Kunci: Open Ended Learning, Problem Solving, Matematik 


\section{PENDAHULUAN}

Matematika adalah suatu bahan kajian yang memiliki konsep abstrak dan dibangun melalui proses penalaran deduktif, yaitu kebenaran suatu konsep diperoleh sebagai akibat logis dari kebenaran sebelumnya yang sudah diterima, sehingga kebenaran antar konsep dalam matematika bersifat sangat kuat dan jelas (Wahyudi, 2015: 68). Selain itu, dalam pembelajaran matematika siswa juga dituntut untuk memiliki kemampuan berpikir logis, kritis, kreatif, sistematis, dan konsisten. Siswa juga dituntut untuk mengembangkan kemampuan pemecahan masalah dalam matematika melalui pola pikir dan kemampuan bernalar agar siswa dapat menyelesaikan suatu permasalahan dan mengkomunikasikan ide atau gagasan dengan menggunakan simbol, tabel, diagram ataupun media lain (Wahyudi, 2015: 68).

Kemampuan pemecahan masalah merupakan bagian dari kurikulum matematika yang penting karena dalam proses pembelajaran siswa dimungkinkan memperoleh pengalaman menggunakan pengetahuan serta keterampilan yang sudah dimilikinya untuk diterapkan pada pemecahan masalah yang bersifat tidak rutin (Roebyanto dan Sri, 2017: 14).

Pada kenyataannya pemecahan masalah masih menjadi kendala dalam pembelajaran terutama dalam pembelajaran matematika. Berdasarkan hasil observasi pada pembelajaran Matematika kelas V di SD Negeri 2 Mekarsari Kecamatan Kutowinangun, Kabupaten Kebumen pada tanggal 10 November 2017 menunjukkan bahwa pemecahan masalah masih rendah. Hal ini dapat dilihat ketika pembelajaran di kelas sedang berlangsung yaitu (1) siswa cenderung pasif untuk mencari pemecahan masalah sendiri, (2) siswa lebih mementingkan hasil daripada proses, terlihat siswa dalam memecahkan masalah lebih mengutamakan hasilnya daripada mengikuti alur atau cara hingga mendapatkan hasil sehingga banyak siswa yang kurang memahami bagaimana jalannya proses pemecahan masalah dalam memecahkan soal matematika, (3) kurangnya pemahaman terhadap masalah yang muncul, terlihat saat siswa diberikan soal matematika siswa mampu membaca, tetapi siswa tidak dapat menentukan inti dari soal tersebut, jika inti masalahnya saja tidak paham maka siswa tidak dapat memperhitungkan jawaban atau solusi dari permasalahan tersebut, dan (4) kesalahan perhitungan, hal ini terjadi karena siswa yang ceroboh atau menganggap mudah suatu soal sehingga ia lalai atau kurang teliti dalam perhitungannya.

Pembelajaran matematika di kelas, guru menggunakan model pembelajaran konvensional seperti ceramah dan tanya jawab namun masih ada banyak kelemahan dalam pelaksanaannya. Pelaksanaan pembelajaran matematika masih berpusat pada guru (teacher center) dan siswa hanya sebagai pendengar. Pembelajaran seharusnya berpusat kepada siswa (student center), guru hanya sebagai fasilitator dan mediator dalam pembelajaran. Guru bahkan jarang menggunakan media pada pembelajaran matematika, jikapun guru menggunakan media, media yang digunakan pun sebatas media cetak.

Berdasarkan hasil pre-test mata pelajaran matematika yang diberikan kepada siswa pada tanggal 02 Desember 2017, menunjukkan bahwa nilai rata-rata matematika dari 30 siswa kelas V SD Negeri 2 Mekarsari yaitu 56,6, sedangkan kriteria ketuntasan minimal (KKM) yang diterapkan yaitu 70 . Baru 4 siswa atau $13 \%$ yang telah lulus KKM dan 26 siswa atau $87 \%$ belum lulus KKM.

Salah satu solusi untuk mengatasi masalah di SD Negeri 2 Mekarsari adalah dengan menerapkan model pembelajaran yang kreatif dan menarik minat siswa untuk belajar. Model pembelajaran adalah suatu perencanaan atau suatu pola yang digunakan sebagai pedoman dalam mendesain pembelajaran secara tatap muka di kelas untuk mencapai suatu tujuan pembelajaran (Trianto, 2014: 53).

Model pembelajaran yang dapat memudahkan siswa dalam menghadapi kesulitan dalam pembelajaran matematika adalah model open ended learning. Model open ended learning atau pembelajaran terbuka adalah proses pembelajaran yang 
didalamnya tujuan dan keinginan individu/ siswa dibangun dan dicapai secara terbuka (Huda, 2017: 278). Maksud terbuka adalah masalah atau soal tersebut memiliki banyak cara penyelesaian dan multijawaban atau lebih dari satu jawaban yang benar. Masalah terbuka juga dapat berarti pembelajaran yang menyajikan permasalahan dengan pemecahan berbagai cara (flexibility) dan solusinya juga bisa beragam (multi jawab, fluency) (Shoimin 2014: 109).

Penerapan model tersebut juga dapat membantu meningkatkan kemampuan siswa dalam pemecahan masalah pada matematika. Mengingat open ended learning adalah pembelajaran terbuka yang berupa soal cerita yang memungkinkan siswa dapat berpikir untuk memecahkan masalahnya. Dalam pembelajarannya sendiri guru dapat mengajukan pertanyaan-pertanyaan yang dapat memancing siswa untuk memecahkan masalahnya sendiri. Guru mendesain agar siswa dapat mencari jawaban atau pemecahan masalah dengan kemungkinan lebih dari satu jawaban ataupun cara penyelesainnya yang lebih dari satu.

Dalam memecahkan masalah peneliti menggunakan empat langkah dalam menyelesaikan masalah dari Polya yaitu (1) memahami masalah, (2) perencanaan pemecahan masalah, (3) melaksanakan perencanaan pemecahan masalah dan (4) melihat kembali kelengkapan pemecahan masalah (Winarni dan Sri, 2016: 124-125).

Berdasarkan uraian diatas, peneliti menggunakan model Open Ended Learning untuk meningkatkan kemampuan pemecahan masalah siswa dalam pembelajaran Matematika di kelas V SDN 2 Mekarsari tahun ajaran 2017/2018.

\section{METODE}

Penelitian ini merupakan penelitian tindakan kelas kolaboratif antara peneliti dengan guru kelas $\mathrm{V}$. Subjek penelitian ini adalah guru dan siswa kelas $\mathrm{V}$ yang berjumlah 30 siswa. Jenis data penelitian ini adalah data kuantitatif berupa penggunaan model Open Ended Learning dan data kualitatif berupa kemampuan pemecahan masalah siswa dalam mata pelajaran Matematika. Sumber data dalam penelitian ini yaitu guru dan siswa kelas $\mathrm{V}$. Teknik pengumpulan data menggunakan observasi, wawancara, dan tes. Uji validitas data menggunakan triangulasi teknik dan sumber. Analisis data meliputi reduksi data, penyajian data, dan kesimpulan sesuai model analisis data menurut Miles dan Huberman (Sugiyono, 2012: 246-253).

Indikator kinerja penelitian ini adalah peningkatan kemampuan pemecahan masalah siswa dalam mata pelajaran Matematika dengan ketercapaian target $85 \%$. Penelitian ini memodifikasi prosedur penelitian Kemmis dan Taggart (Arikunto, 2013: 137), yaitu terdiri dari tahap perencanaan, pelaksanaan, pengamatan, dan refleksi.

\section{HASIL DAN PEMBAHASAN}

Penelitian ini dilaksanakan selama tiga siklus dengan menerapkan enam langkah model Open Ended Learning yaitu: (1) orientasi, (2) penyajian masalah terbuka, (3) pengerjaan masalah terbuka secara individu, (4) diskusi kelompok, (5) presentasi hasil diskusi kelompok, dan (6) penutup.

Hasil observasi penerapan model Open Ended Learning terhadap guru dan siswa mengalami peningkatan pada setiap siklusnya hingga mencapai indikator kinerja penelitian yang ditargetkan yaitu $85 \%$. Hasil observasi kegiatan guru pada siklus I $72,68 \%$, meningkat pada siklus II menjadi $82,64 \%$, kemudian pada siklus III mencapai $90,98 \%$. Sedangkan kegiatan siswa pada siklus I memperoleh rata-rata sebesar $70,37 \%$, meningkat pada siklus II menjadi $78,58 \%$, kemudian pada siklus III mencapai $86,10 \%$. Berdasarkan hasil observasi dan wawancara, guru berhasil menerapkan langkah langkah model Open Ended Learning dan siswa aktif mengikuti pembelajaran dengan baik. 
Hasil belajar tentang kemaampuan pemecahan masalah dapat di lihat pada tabel di bawah ini.

\begin{tabular}{llccc}
\hline No & Perbandingan & $\begin{array}{c}\text { Siklus } \\
\text { I }\end{array}$ & $\begin{array}{c}\text { Siklus } \\
\text { II }\end{array}$ & $\begin{array}{c}\text { Siklus } \\
\text { III }\end{array}$ \\
\hline 1 & Rata-rata nilai & 67,97 & 73,50 & 82,60 \\
\hline 2 & Siswa tuntas & $60 \%$ & $79 \%$ & $86,7 \%$ \\
\hline 3 & $\begin{array}{l}\text { Siswa belum } \\
\text { tuntas }\end{array}$ & $40 \%$ & $21 \%$ & $13,3 \%$ \\
\hline
\end{tabular}

Dengan demikian penggunaan model Open Ended Learning dapat meningkatkan kemampuan pemecahan masalah siswa dalam mata pelajaran Matematika dilihat dari persentase siswa yang memenuhi ketercapaian target dari siklus I-III. Hasil penelitian ini memperkuat penelitian yang dilakukan Alim dan Jalinus (2015) dan Sitanggang (2010) yang menyatakan bahwa penggunaan pendekatan Open Ended dapat meningkatkan kemampuan pemecahan masalah siswa dilihat dari hasil belajar siswa berdasarkan tingkat pencapaian indikator kemampuan pemecahan masalah yaitu memahami masalah, merencanakan pemecahan masalah, melaksanakan perencanaan pemecahan masalah dan melihat kembali.

\section{SIMPULAN}

Penerapan model pembelajaran Open Ended Learning dapat meningkatkan kemampuan pemecahan masalah siswa dalam mata pelajaran Matematika Kelas V SD Negeri 2 Mekarsari tahun ajaran 2017/2018, dibuktikan dengan peningkatan persentase hasil belajar siswa siswa yang memenuhi ketercapaian target kemampuan pemecahan masalah siswa sebesar $85 \%$.

Berkaitan dengan hasil penelitian yang telah dicapai, peneliti mengajukan saran sebagai berikut: (1) bagi guru, diharapkan dapat mengembangkan model Open Ended Learning pada materi atau mata pelajaran lain; (2) bagi sekolah, diharapkan melengkapi sarana dan prasarana pendukung pembelajaran; dan (3) bagi peneliti lain, keberhasilan penelitian ini dapat digunakan sebagai dasar pijakan pengembangan penelitian yang menerapkan model Open Ended Learning untuk meningkatkan kemampuan pemecahan masalah siswa pada mata pelajaran lain. 


\section{DAFTAR PUSTAKA}

Alim, J.A dan Jalinus. (2015). Pembelajaran Open-Ended untuk Meningkatkan Kemampuan Pemecahan Masalah Matematika (Penelitian Eksperimen Pada Siswa Kelas IV SDN 034 Tarai Bangun Kecamatan Tambang Kabupaten Kampar). Educational Community and Cultural Diversity.

Arikunto, S. (2013). Prosedur Penelitian: Suatu Pendekatan Praktik. Jakarta: Rineka Cipta.

Huda, M. (2015). Cooperative Learning Metode Teknik Struktur dan Model Terapan. Yogyakarta: Pustaka Pelajar.

Roebyanto, G Dan Sri, H. (2017). Pemecahan Masalah Matematika untuk PGSD. Bandung: PT Remaja Rosdakarya.

Shoimin, A. (2014). 68 Model Pembelajaran Inovatif Dalam Kurikulum 2013. Yogyakarta : Ar-Ruzz Media.

Sitanggang, A.K. (2010). Meningkatkan Kemampuan Pemecahan Masalah Matematika Siswa SD melalui Pendekatan Open Ended.

Sugiyono. (2012). Metode Penelitian Pendidikan (Pendekatan Kuantitatif, Kualitatif, dan $R \& D)$. Bandung: Penerbit Alfabeta.

Trianto. (2014). Model Pembelajaran Terpadu: Konsep, Strstegi, dan Implementasinya dalam Kurikulum Tingkat Satuan Pendidikan (KTSP). Jakarta: Bumi Aksara.

Wahyudi. (2015). Panduan Pembeljaaran Matematika Sekolah Dasar (untuk Guru dan Calon Guru). Surakarta : Uns Press.

Winarni, E,S dan Sri, H. (2012). Matematika untuk PGSD. Bandung: PT Remaja Rosdakarya. 